\title{
CLASSIFICATION OF MEAT IMAGERY USING ARTIFICIAL NEURAL NETWORK METHOD AND TEXTURE FEATURE EXTRACTION BY GRAY LEVEL CO- OCCURRENCE MATRIX METHOD
}

\author{
Chairul Imam $^{* 1}$, Eka Wahyu Hidayat ${ }^{2}$, Neng Ika Kurniati ${ }^{3}$ \\ 1,2,3 Informatika, Universitas Siliwangi, Indonesia \\ Email: ${ }^{1}$ 1570060013@ student.unsil.ac.id , ${ }^{2}$ ekawahyu@ unsil.ac.id, ${ }^{3}$ nengikakurniati@unsil.ac.id
}

(Naskah masuk: 20 November 2020, diterima untuk diterbitkan: 17 Desember 2020)

\begin{abstract}
Lately, there is often a mixture of beef and pork done by traders to the general public as buyers. This is due to the unconsciousness of the buyer on how to recognize the type of meat purchased. The effect of this meat mix can certainly be detrimental to buyers, especially Muslims. Image processing is a general term for various methods in which it is used to manipulate and modify images in various ways. Classification is a method of grouping some information and ensuring it is listed in a class. Classification of beef and pork differentiator in this application using Artificial Neural Network (ANN) method while for texture extraction using Gray Level Cooccurrence Matrix (GLCM) method. The information used in the examination was 30 images of fresh meat divided into 15 images of fresh beef and 15 images of fresh pork. The data used is data Classification of Beef and Pork Image based on Color and Texture Characteristics. The result of classification accuracy obtained in this application is $80 \%$.
\end{abstract}

Keywords: artificial neural network, gray level co-occurrence matrix, image processing, meat consumption, personal extreme programming.

\section{KLASIFIKASI CITRA DAGING MENGGUNAKAN METODE JARINGAN SARAF TIRUAN DAN EKSTRAKSI CIRI TEKSTUR DENGAN METODE GRAY LEVEL CO-OCCURRENCE MATRIX}

\begin{abstract}
Abstrak
Akhir-akhir ini, sering terjadi percampuran daging antara daging sapi dan daging babi yang dilakukan oleh pedagang kepada masyarakat umum sebagai pembeli. Hal ini terjadi karena ketidaksadaran pembeli tentang cara mengenali jenis daging yang dibeli. Efek percampuran daging ini tentusaja dapat merugikan pembeli terutama umat muslim. Pengolahan citra merupakan istilah umum untuk berbagai metode yang keberadaannya untuk memanipulasi serta memodifikasi citra dengan berbagai cara. Klasifikasi merupakan sesuatu metode untuk mengelompokkan sebagian informasi serta memastikan informasi tersebut tercantum dalam sesuatu kelas. Klasifikasi pembeda daging sapi dan daging babi pada aplikasi ini menggunakan metode Jaringan Saraf Tiruan (JST) sedangkan untuk ekstraksi ciri tekstur menggunakan metode Gray Level Co-occurrence Matrix (GLCM). Informasi yang digunakan dalam pemeriksaan adalah 30 citra daging segar dibagi menjadi 15 citra daging sapi segar dan 15 citra daging babi segar. Data yang digunakan adalah data Klasifikasi Citra Daging Sapi dan Daging Babi Berdasarkan Ciri Warna dan Tekstur. Hasil akurasi klasifikasi yang diperoleh pada aplikasi ini sebesar $80 \%$
\end{abstract}

Kata kunci: daging konsumsi, gray level co-occurrence matrix, jaringan saraf tiruan, pengolahan citra, personal extreme programming.

\section{PENDAHULUAN}

Daging adalah bahan pangan yang mengandung gizi tinggi untuk memenuhi kebutuhan asam amino esensial yang memberikan beragam manfaat untuk tubuh manusia dan merupakan sumber vitamin B kompleks dan lemak pada daging memiliki kandungan vitamin - vitamin yang bermanfaat bagi tubuh manusia [1]. Tingkat konsumsi daging yang sangat tinggi sehingga daging konsumsi tersebut banyak ditemukan di pasar. Normalnya, pedagang menjual daging konsumsi tersebut sesuai dengan jenisnya, tetapi karena ada beberapa pedagang khususnya di Indonesia ingin memperoleh keuntungan yang sebesar-besarnya. 
Kadang - kadang pedagang melakukan tindakan kecurangan yang biasanya bertujuan untuk meningkatkan jumlah daging dan melakakukan pencampuran daging konsumsi. Daging konsumsi yang biasanya dicampur antara lain, daging sapi dengan babi. Banyak pembeli tidak mengetahui tentang pencampuran daging - daging tersebut, karena membedakan antara daging sapi dengan daging babi sangat sulit dikenali oleh orang awam. Kegiatan pencampuran ini merugikan pembeli, khususnya muslim yang dilarang memakan daging babi, sesuai dengan firman Allah SWT yang tercantum di dalam Al-Qur'an (QS. Al-Baqarah : 173, QS. Al-Maidah : 3, QS. Al-An'am : 145, QS. An-Nahl : 115). Identifikasi yang dilakukan selama ini hanya dilakukan secara manual dengan indera penglihatan (mata) dan indera penciuman (hidung) manusia. Cara ini mempunyai banyak kelemahan dikarenakan kemampuan manusia yang tidak konsisten, terdapat perbedaan presepsi masing masing pengamat, selain itu juga cara ini memerlukan waktu yang lama.

Pengolahan citra (image processing) adalah proses gambar dua dimensi melalui PC/komputer digital [2]. Pengolahan citra merupakan istilah umum untuk berbagai metode yang keberadaannya untuk memanipulasi serta memodifikasi citra dengan berbagai cara, seperti : cara [3] dan cara [4]. Klasifikasi merupakan prosedur logis yang merangkai suatu hal dan dirancangan untuk saling berkaitan satu dan yang lainnya, dengan klasifikasi juga akan menjadikan sebuah hasil yang dimaksud [5]. Jaringan Saraf Tiruan (JST) ataupun Artificial Neural Network( ANN) merupakan suatu jaringan yang dirancang seperti otak manusia yang bertujuan untuk melakukan sesuatu tugas tertentu. Jaringan ini umumnya diimplementasikan dengan memakai komponen elektronik ataupun disimulasikan pada aplikasi PC [6]. Gray Level Co-Occurrence Matrix (GLCM) merupakan metode untuk melakukan ekstraksi ciri tekstur bebrbasis statistikal, ciri diperoleh dari nilai piksel matrik yang mempunyai nilai tertentu dan membentuk suatu sudut pola [7].

Proses aplikasi ini dengan cara ekstraksi citra daging menggunakan Gray Level Co-occurence Matrix $(G L C M)$ dan pengklasifikasiannya menggunakan Jaringan Saraf Tiruan (JST). Hasil ekstraksi GLCM yang terbentuk dapat diklasifikasi menggunakan Jaringan Saraf Tiruan (JST). Ekstraksi ciri tekstur berupa nilai piksel matrik yang sudah diperoleh akan menjadi sebuah input pada Jaringan Saraf Tiruan (JST) dikarenakan telah menjadi salah satu alat yang penting dalam proses klasifikasi. Setelah itu akan diuji tingkat akurasi hasil pemrosesan klasifikasi tersebut.

Tujuan dari pembuatan aplikasi atau software ini untuk klasifikasi antara daging sapi dan daging babi dengan ekstrasi citra berdasarkan tekstur menggunakan Gray Lecel Co-occurrence Matrix (GLCM) dan klasifikasinya menggunakan Jaringan
Saraf Tiruan (JST), selain itu pembuatan aplikasi ini juga bertujuan untuk membandingkan tingkat akurasi sesuai saran dengan penelitian sebelumnya dengan judul "Klasifikasi Citra Daging Sapi dan Daging Babi Berdasarkan Ciri Warna dan Tekstur" oleh Winda Rizky Astuti pada tahun 2016 dengan hasil akurasi klasifikasi terbesar mencapai 94\%[8]. Data yang digunakan sebanyak 130 citra (100 citra pelatihan dan 30 citra pengujian) dari penelitian sebelumnya.

\section{METODE PENELITIAN}

\subsection{Gray Level Co-occurrence Matrix (GLCM)}

Menerapkan analisis citra bersumber pada distribusi dari intensitas pikselnya, dilakukan dengan cara mengekstrak fitur teksturnya. GLCM merupakan sebuah metode untuk melakukan ekstraksi ciri bebrbasis statistikal, perolehan ciri diperoleh dari nilai piksel matrik yang memiliki nilai tertentu serta membentuk suatu sudut pola. Sudut yang dibentuk dari nilai piksel citra menggunakan GLCM ialah sudut $0^{\circ}, 45^{\circ} .90^{\circ}, 135^{\circ}$. [7] dan [9].

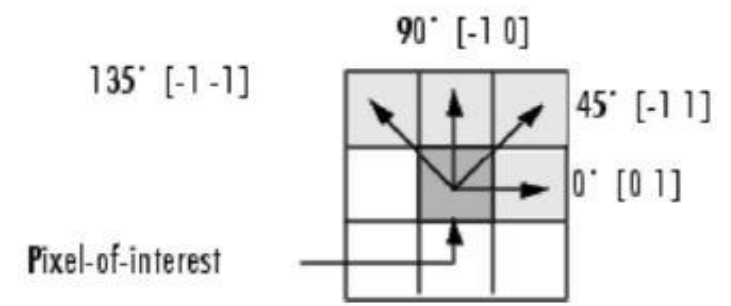

Gambar 1. Piksel berbagai sudut

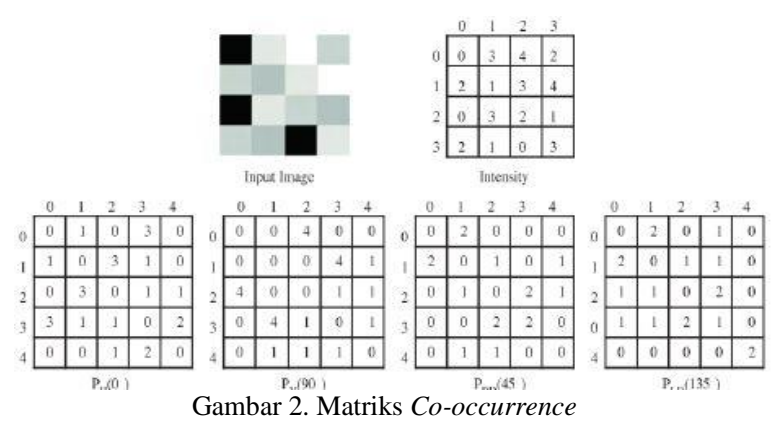

Piksel - piksel tersebut membentuk sebuah matrik co-occurrence dengan pasangan pikselnya. Hal tersebut berdasarkan bahwa kondisi sebuah matrik piksel mempunya nilai perulangan sehingga terdapat pasangan keabuannya [10]. Nilai piksel tersebut merupakan matrik dengan jarak 2 (dua) posisi yaitu, $\left(\mathrm{x}_{1}, \mathrm{y}_{1}\right)$ serta $\left(\mathrm{x}_{2}, \mathrm{y}_{2}\right)$. Bersumber pada kondsi tersebut, untuk membedakan antar matrik citra dapat dilihat berdasarkan ciri matrik dengan memakai persamaan sebagai berikut :

$$
\begin{array}{r}
\text { Menghitung Contras } \\
f_{1}=\sum_{i} \sum_{j}(i-j)^{2} p_{d}(i, j)
\end{array}
$$

Contras, fitur contras digunakan untuk menghitung tingkat berbedaan abu - abu dalam 
suatu gambar, semakin besar perbedaan semakin tinggi kontrasnya dan sebaliknya semakin sedikit perbedaan keabu - abuan antara dua piksel, semakin rendah kontrasnya.

$$
\text { - Menghitung Energy }
$$

$$
f_{2}=\sum i, j p_{2}^{d}(i, j)
$$

Energy, nilai energi menggambarkan tingkat distribusi keabu - abuan sebuah gambar.

$$
\text { - Menghitung Correlation }
$$

$$
f_{3}=\sum_{i} \sum_{j} \frac{(i-\mu i)(j-\mu j) p_{(i, j)}}{\sigma_{i} \sigma_{j}}
$$

Correlation, memunculkan bagaimana korelasi referensi piksel dengan tetangganya.

$$
\begin{gathered}
f_{4}=\sum_{i} \sum_{j} \frac{p_{d}(i, j)}{i+|i-j|}
\end{gathered}
$$

Homogeneity, fitur homogenitas menghitung tingkat homogenitas abu - abu dalam suatu gambar. Nilai homogenitas lebih tinggi di gambar tingkat abu - abu yang hampir sama.[11][12].

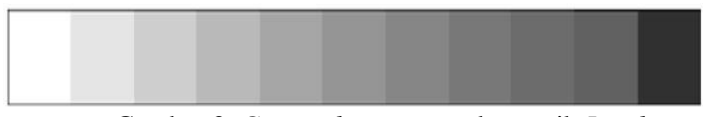

Gambar 3. Grayscale atau monokromatik Level

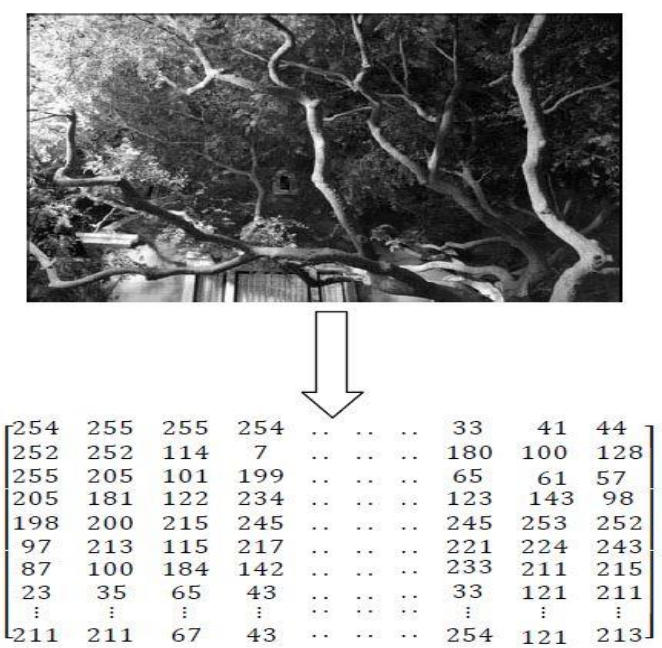

Gambar 4. Citra Grayscale yang diubah menjadi nilai matriks.

\subsection{Citra Grayscale atau Citra Monokromatik}

Suatu citra dikatakan citra grayscale apabila suatu citra tidak memiliki warna RGB (Red, Green Blue) maupun dapat dikatakan suatu citra yang memiliki nilai dari putih yang memiliki intensitas sangat besar sampai hitam/gelap yang memiliki intensitas lebih rendah. Citra grayscale terdiri dari $\mathrm{x}$ dan y dalam spasial koordinat dan mempunyai nilai intensitasnya masing - masing. Pada citra grayscale masing- masing gambar memiliki intensitas antara 0 (hitam/ gelap) hingga 255 (putih) dalam citra 8 bitnya [13].
Contoh Citra grayscale dapat ditunjukkan oleh gambar 3, sedangkan citra grayscale yang diubah menjadi nilai matriks dapat ditunjukkan oleh gambar 4.

\subsection{Artificial Neural Networl (ANN) atau Jaringan Saraf Tiruan (JST)}

JST merupakan sebuah metode pemodelan data statistik non-linier. JST dapat digunakan untuk memodelkan hubungan yang kompleks antara input dan output untuk menemukan pola-pola pada data. JST menyerupai otak manusia dalam 2 perihal :

1. Pengetahuan yang didapat dari jaringan lingkungan melalui proses pendidikan/pembelajaran.

2. Tenaga koneksi Interneuron, yang dikenal sebagai bobot sinaptik (synaptic weights), yang digunakan untuk menaruh/menyimpan pengetahuan yang didapat. [6], [9] dan [14]

\subsection{Algoritma Backpropagtion atau Propagasi Mundur}

Backpropagation ialah sesuatu metode sistematik untuk pelatihan multilayer JST. Backpropagation dikatakan algoritma pelatihan multilayer sebab Backpropagation memiliki 3(tiga) layer dalam proses pelatihannya, antara lain input layer, hidden layer dan output layer, Backpropagation ini ialah perkembagan dari single layer network (jaringan layar tunggal) yang memiliki 2 (dua) layer, ialah input layer dan output layer. Dengan terdapatnya hidden layer pada Backpropagation dapat memunculkan besarnya tingkatan error pada Backpropagation lebih kecil dibanding tingkatan error pada single layer network. Perihal demikian diakibatkan hidden layer pada Backpropagation berfungsi bagaikan tempat untuk mengupdate serta membiasakan bobot yang ada, sehingga didapatkan nilai bobot yang baru yang bisa diarahkan mendekati dengan target output yang diinginkan. [15], [16] dan [7].

Terdapat 3 tahapan dalam algoritma backpropagation yaitu : [16]

1. Feedforward

- Menghitung znet

$z_{-}$net $_{j}=v_{j o} \sum_{i=1 x_{i} \cdot v_{j i}}^{n}$

- Menghitung nilai aktivasi

$z_{j}=f\left(z_{-}\right.$net $\left._{j}\right)=\frac{1}{1+e^{(-z n e t j)}}$

- Menghitung hasil output

$y_{-} n e t_{k}=w_{k o} \sum_{i=1 z_{i} \cdot w_{j i}}^{n}$

- Menghitung nilai aktivasi

$$
y_{k}=f\left(y_{-} n e t_{k}\right)=\frac{1}{1+e^{\left(-y_{\text {netk }}\right)}}
$$


2. Backpropagation Error

- Menghitung nilai $\delta k$

$\delta_{k}=\left(t_{k}-y_{k}\right) y_{k}\left(1-y_{k}\right)$

- Menghitung nilai $w_{k j}$

$\square w_{k j}=a \cdot \delta_{k} \cdot z_{j}$

- Menghitung nilai $\delta$ net

$\delta_{-}$net $_{j}=\sum_{k=1}^{m} \delta_{k w_{k j}}$

- Menghitung nilai $\delta j$

$\delta_{j}=\delta_{n e t j} z_{j}\left(1-z_{j}\right)$

- Menghitung nilai $v_{i j}$

$\square v_{k j}=a \cdot \delta_{j} \cdot z_{j}$

3. Weight Update

- Melakukan update bobot $w_{k j}$

$w_{k j}($ baru $)=w_{k j}($ lama $)+\square w_{k j}$

- Melakukan update bobot $v_{j i}$

$v_{j i}($ baru $)=v_{j i}(\operatorname{lama})+\square v_{j i}$

\subsection{Recognition Rate atau Tingkat Pengakuan}

Perhitungan akurasi pada sebuah klasifikasi berpengaruh terhadap performa dari metode dalam klasifikasi yang digunakan. Akurasi merupakan salah satu parameter uji yang menentukan kelayakan dari sebuah sistem dalam klasifikasi [17]. Banyak cara untuk menghitung akurasi dari klasifikasi, diantaranya menggunakan recognition rate. Rumus perhitungan recognition rate sebagai berikut :

Recognition Rate $=\frac{\sum \text { Correct }}{\sum \text { Sample }} \times 100 \%$

Keterangan :

$\sum$ Correct $=$ Jumlah data benar

$\sum$ Sample $=$ Jumlah data seluruhnya

\section{HASIL DAN PEMBAHASAN}

Metode penelitian yang dilakukan menggunakan metode eksperimental, untuk meneliti pengaruh algoritma klasifikasi menggunakan Jaringan Saraf Tiruan (JST) dan ekstraksi menggunakan Gray Level Co-occurence Matrix (GLCM) pada objek penelitian berupa citra daging halal (sapi) dan haram (babi) yang diambil dari internet, supaya mampu mengklasifikasi antara citra daging halal (sapi) dan haram (babi). Alur penelitian ini digambarkan dalam bagan gambar 5 .

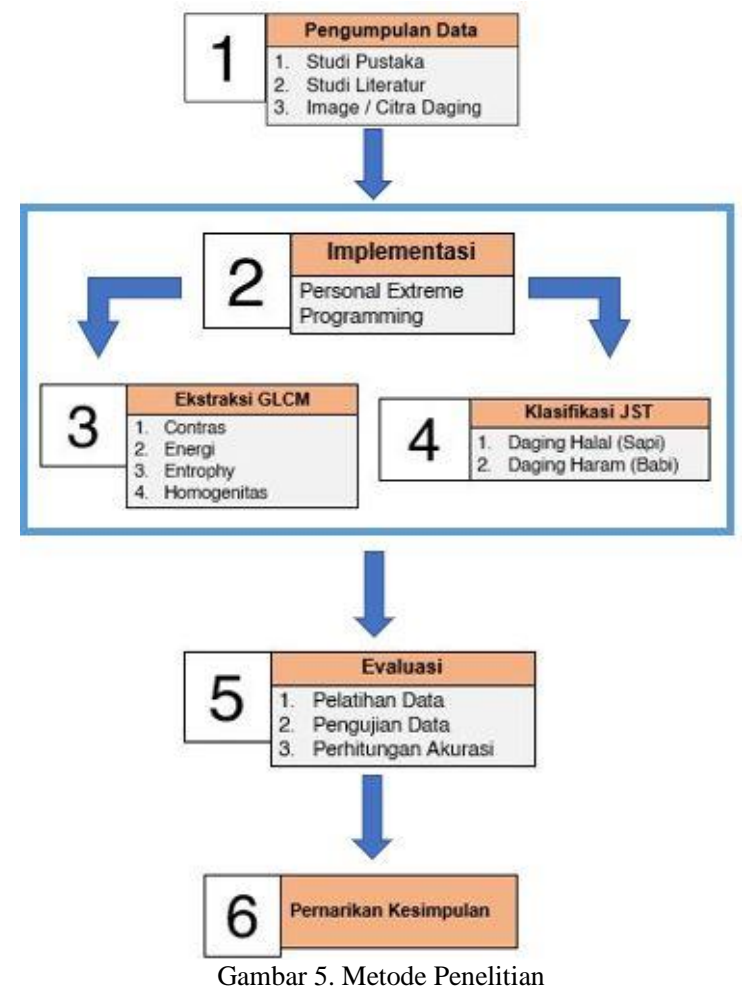

\subsection{Pengumpulan Data}

Pengumpulan data guna untuk mendapatkan data-data yang relevan untuk penelitian, pengumpulan data dilakukan dengan tiga cara, yaitu studi pustaka, studi literatur dan pengumpulan Image/citra.

Studi pustaka merupakan Kegiatan menghimpun informasi yang relevan dan mendapatkan pemahaman konsep-konsep secara teoritis, informasi ini diperoleh dari buku dan $e$ book. Informasi yang dihimpunin diantranya algoritma Gray Level Co-occurence Matrix (GLCM) dan Jaringan Saraf Tiruan (JST).

Studi literatur merupakan kegiatan menghimpun informasi yang relevan dan mendapatkan pemahaman konsep - konsep secara teoritis, informasi ini di peroleh dari jurnal. Informasi yang dihimpunin diantranya algoritma Gray Level Co-occurence Matrix (GLCM) dan Jaringan Saraf Tiruan (JST).

Pengumpulan Image/Citra. Diambil 130 citra dibagi menajdi 100 citra untuk pelatihan dan 30 citra untuk pengujian. Cita diambil dari penelitian sebelumnya dengan ukuran $255 \times 255$ pixel. Tabel asset image sapi dan babi yang telah didapatkan dapat ditunjukkan oleh tabel 1 dan 2 .

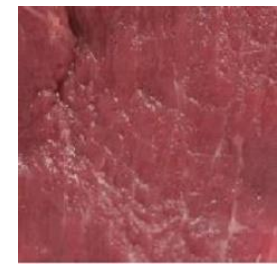

Gambar 6. UjiSapi1.jpg 
Contoh citra uji daging babi yang diambil dari penelitian sebelumnya dapat ditunjukkan oleh gambar 7.

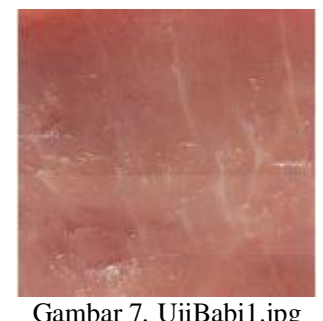

Tabel 1. Asset image sapi

\begin{tabular}{cccc}
\hline No & Nama Image & Sumber & Ukuran \\
\hline 1 & UjiSapi1.jpg & Astuti, 2016 & $13,4 \mathrm{~KB}$ \\
2 & UjiSapi2.jpg & Astuti, 2016 & $30,1 \mathrm{~KB}$ \\
3 & UjiSapi3.jpg & Astuti, 2016 & $24,7 \mathrm{~KB}$ \\
4 & UjiSapi4.jpg & Astuti, 2016 & $29,9 \mathrm{~KB}$ \\
5 & UjiSapi5.jpg & Astuti, 2016 & $27,7 \mathrm{~KB}$ \\
6 & UjiSapi6.jpg & Astuti, 2016 & $21,9 \mathrm{~KB}$ \\
7 & UjiSapi7.jpg & Astuti, 2016 & $24,7 \mathrm{~KB}$ \\
8 & UjiSapi8.jpg & Astuti, 2016 & $27,1 \mathrm{~KB}$ \\
9 & UjiSapi9.jpg & Astuti, 2016 & $25,1 \mathrm{~KB}$ \\
10 & UjiSapi10.jpg & Astuti, 2016 & $28,6 \mathrm{~KB}$ \\
11 & UjiSapi11.jpg & Astuti, 2016 & $11,8 \mathrm{~KB}$ \\
12 & UjiSapi12.jpg & Astuti, 2016 & $12,0 \mathrm{~KB}$ \\
13 & UjiSapi13.jpg & Astuti, 2016 & $28,1 \mathrm{~KB}$ \\
14 & UjiSapi14.jpg & Astuti, 2016 & $24,8 \mathrm{~KB}$ \\
15 & UjiSapi15.jpg & Astuti, 2016 & $23,9 \mathrm{~KB}$ \\
\hline
\end{tabular}

Tabel 2. Asset image Babi

\begin{tabular}{cccc}
\hline No & Nama Image & Sumber & Ukuran \\
\hline 1 & UjiBabi1.jpg & Astuti, 2016 & $10,6 \mathrm{~KB}$ \\
2 & UjiBabi2.jpg & Astuti, 2016 & $10,5 \mathrm{~KB}$ \\
3 & UjiBabi3.jpg & Astuti, 2016 & $19,0 \mathrm{~KB}$ \\
4 & UjiBabi4.jpg & Astuti, 2016 & $23,0 \mathrm{~KB}$ \\
5 & UjiBabi5.jpg & Astuti, 2016 & $25,0 \mathrm{~KB}$ \\
6 & UjiBabi6.jpg & Astuti, 2016 & $24,5 \mathrm{~KB}$ \\
7 & UjiBabi7.jpg & Astuti, 2016 & $23,5 \mathrm{~KB}$ \\
8 & UjiBabi8.jpg & Astuti, 2016 & $22,9 \mathrm{~KB}$ \\
9 & UjiBabi9.jpg & Astuti, 2016 & $11,4 \mathrm{~KB}$ \\
10 & UjiBabi10.jpg & Astuti, 2016 & $21,6 \mathrm{~KB}$ \\
11 & UjiBabi11.jpg & Astuti, 2016 & $24,4 \mathrm{~KB}$ \\
12 & UjiBabi12.jpg & Astuti, 2016 & $24,5 \mathrm{~KB}$ \\
13 & UjiBabi13.jpg & Astuti, 2016 & $23,8 \mathrm{~KB}$ \\
14 & UjiBabi14.jpg & Astuti, 2016 & $22,2 \mathrm{~KB}$ \\
15 & UjiBabi15.jpg & Astuti, 2016 & $22,5 \mathrm{~KB}$ \\
\hline
\end{tabular}

\subsection{Personal Extreme Programming (PXP)}

Model yang digunakan dalam membangun aplikasi yang akan dibuat menggunakan Personal Extreme Programing (PXP), PXP dapat digunakan untuk menangani situasi proses pengembangan software dengan pemrogram tunggal. Pada tahapan pertama yaitu requirement proses ini meliputi kegiatan mengenai analisis kebutuhan dan penetapan pelaksanaan pembangunan aplikasi. Proses kedua menentukan fungsional keseluruhan yang akan dikembangkan oleh sistem serta penentuan perencanaan dalam tahap pembuatan aplikasi. Proses ketiga yaitu iteration initialization, pada proses ini melakukan pemilihan fitur yang hendak diimplementasikan selama iterasi. Fitur diseleksi bersumber pada prioritas dengan urutan must have, should have, could have serta wouldn't have sesuai dengan daftar iterasi dalam hasil release planning. Proses ke empat yaitu design proses ini melakukan desain perancangan flowchart dan Unified Modeling Language UML Tahapan ke lima yaitu implementation delakukan pengkodean sistem menggunakan Matlab 2017a, dan pengujian saat pengkodean sebagai unit testing, apabila terdapat kesalahan maka akan dilakukan koreksi ulang ataupun refactor pada tahap dimana kesalahan bermula, apabila tidak terdapat kesalahan maka dilanjutkan pada unit berikutnya.Tahapan yang ketujuh ialah system testing merupakan tahapan diujinya fungsionalitas sistem secara keseluruhan. Tahapan yang terakhir yaitu retrospective ialah tahap pengambilan kesimpulan terhadap sistem, apabila sistem masih terdapat kesalahan maka akan dilakukan revisi/perbaikan mulai dari tahapan Iteration Initialization

\subsection{Proses Identifikasi}

Dimulai dengan melakukan input citra ke dalam sistem, lalu citra yang telah di input dilakukan proses ekstraksi ciri tekstur menggunakan (GLCM) dan terakhir di klasifikasikan menggunakan (JST) apakah citra tersebut termasuk ke dalam citra daging sapi (halal) atau daging babi (haram). Jika ingin memulai identifikasi baru sistem harus di reset terlebih dahulu.

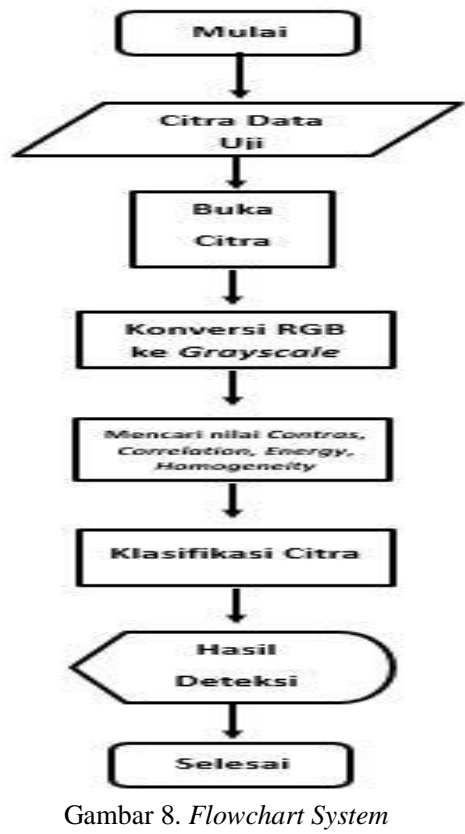

\subsection{Ekstraksi GLCM}

Pengumpulan Hasil ekstraksi menggunakan Gray, Level Co-Occurence Matrix (GLCM) merupakan parameter - parameter yang nantinya menjadi pembeda antara daging sapi dan daging babi. Parameter - parameter tersebut antara lain, Contras, Energi, Entropy dan Homogenitas. Proses ekstraksi dan flowchart dari GLCM dapat ditunjukkan oleh gambar 9 . 


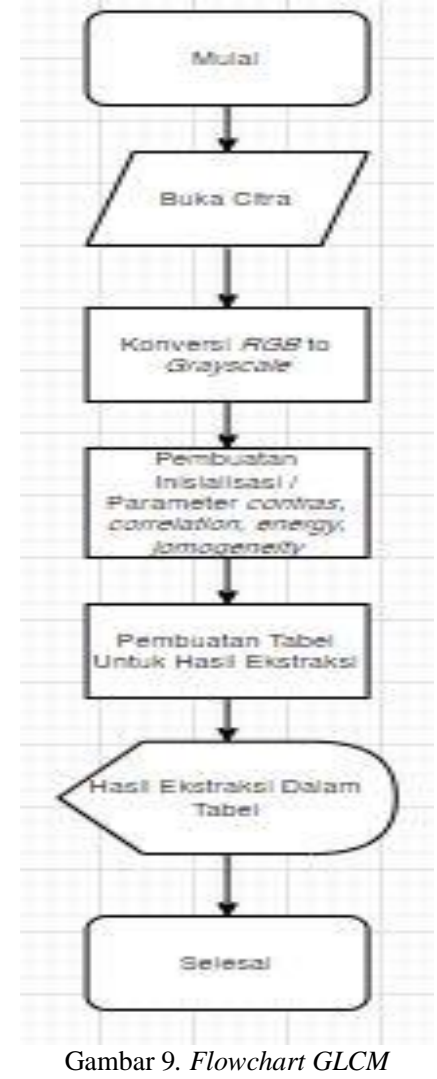

\subsection{Klasifikasi JST}

Hasil klasifikasi menggunakan Jaringan Saraf Tiruan (JST) merupakan pengklasifikasian antara citra daging sapi dan daging babi yang telah diekstraksi menggunakan GLCM.

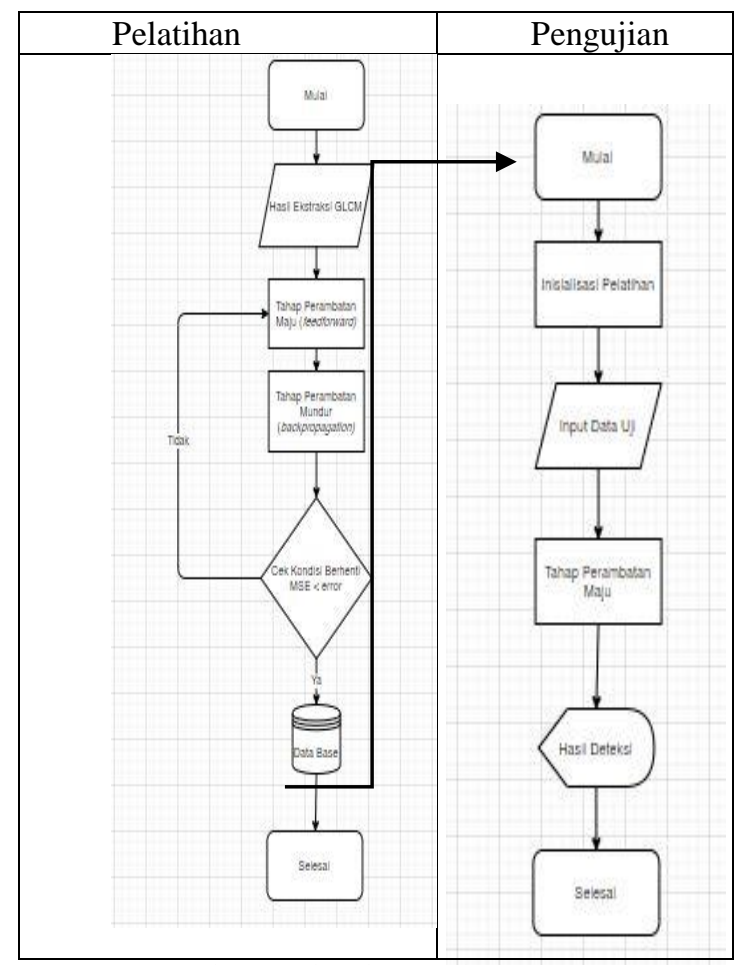

Gambar 10. Flowchart Backpropagation
Parameter untuk pelatihan Backpropagation sebagai berikut :

net $=\left[\begin{array}{ll}10 & 5\end{array}\right]$

net.trainParam.epochs $=10$

net.trainParam.goal $=1 \mathrm{e}-6$

\subsection{Evaluasi}

Evaluasi mengenai data latih dan data uji dapat ditunjukkan sebagai berikut :

1. Data latih berjumlah 100 citra (50 citra daging sapi dan 50 citra daging babi) untuk pengambilan parameter yang digunakan sebagai pelatihan dalam aplikasi yang akan dibuat.

2. Data Uji, merupakan 30 citra (15 citra daging sapi dan 15 citra daging babi) untuk menentukan tingkat akurasi klasifikasi pada aplikasi yang akan dibuat.

3. Perhitungan akurasi, proses ini melakukan penentuan tingkat akurasi dari hasil klasifikasi pada aplikasi yang akan dibuat.

\subsection{Penarikan Kesimpulan}

Kesimpulan diambil dari hasil pembahasan, mengenai model rekayasa perangkat lunak yang digunakan untuk pembuatan aplikasi, cara ektraksi menggunakan GLCM dan klasifikasi menggunakan JST serta tingkat akurasi hasil klasifikasi.

Aplikasi yang dibuat sebagai capaian akhir mampu memecahkan masalah yang dihadapi atau tidak. Aplikasi dapat dikatakan berhasil memenuhi kebutuhan apabila, mampu mengklasifikasi antara daging sapi dan daging babi dengan metode GLCM dan JST pada citra yang diambil dari penelitian sebelumnya. Hasil dari aplikasi berupa klasifikasi pembeda antara daging sapi, daging babi dan tingkat akurasi hasil pendeteksian diatasi $75 \%$.

\section{IMPLEMENTASI SISTEM}

Implementasi dimulai dengan membuat desain interface, lalu memberikan fungsi ke masing masing komponen pada sistem. Hasil implementasi sistem dapat dilihat pada Gambar 11.

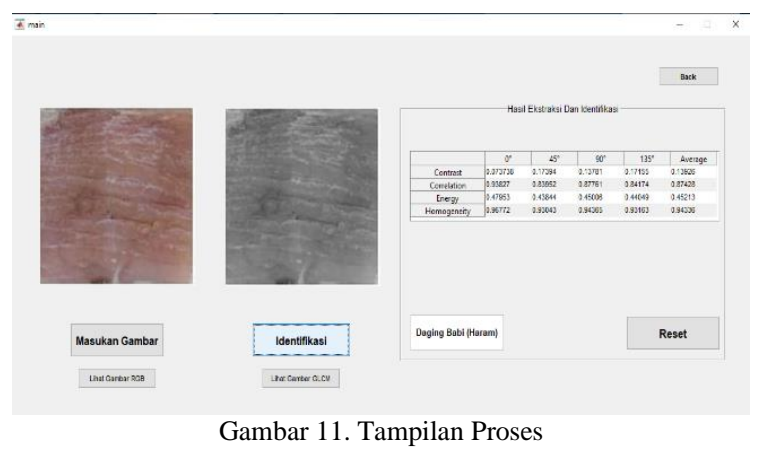

Perancangan untuk aplikasi ini menggunakan Use Case diagram dan Class diagram 


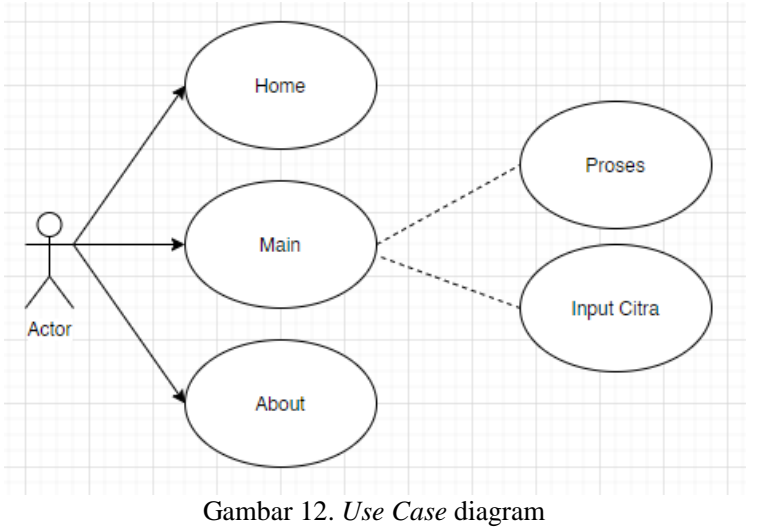

Dari Use Case diagram pada gambar 9 menjelaskan mengenai Use Case diagram yang dibuat berdasarkan perancangan pada aplikasi yang akan dibuat. Use Case diagram merupakan diagram yang bekerja untuk mendeskripsikan interaksi antara user dengan sistem melalui sebuah alur bagaimana sistem akan digunakan. Use case diagram terdiri dari sebuah actor dan interaksi yang dilakukannya. Actor tersebut berupa manusia sebagai pengguna dari aplikasi tersebut. Use Case diagram yang dibuat, Actor dapat melakukan proses input citra pada menu utama.

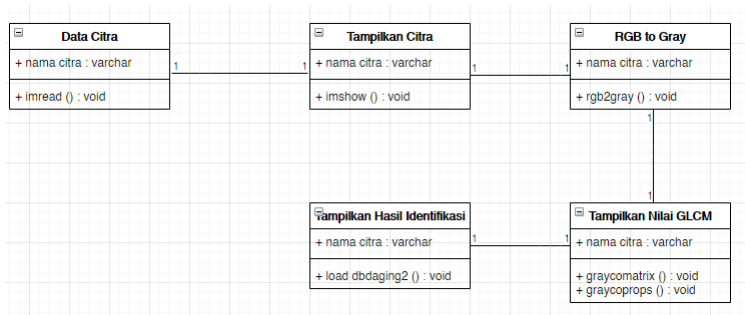

Gambar 13. Class diagram

Menampilkan hasil dari Class diagram yang digunakan dalam perancangan aplikasi yang dibuat. Class data citra yaitu class yang memiliki atribut nama citra dan dapat melakukan proses mengambil data citra. Class Tampilkan Citra terdiri dari atribut nama citra dan dapat melakukan proses menampilkan citra. Class RGB to Gray memiliki atribut nama citra dan dapat melakukan proses mengubah citra RGB ke Gray lalu akan di tampilkan hasil proses perubahannya. Class Tampilkan Nilai GLCM terdiri dari atribut nama citra dan dapat melakukan proses menentukan nilai Contras, Correlation, Energy dan Homogeneity lalu akan di tampilkan hasilnya. Class Tampilkan Hasil Identifikasi terdiri dari atribut nama citra dan melakukan pengambilan data dari database yang sudah dibuat sebelumnya dan dapat menampilkan hasil deteksi.

\subsection{Hasil Proses Ekstraksi GLCM}

Hasil proses ekstraksi GLCM dapat ditunjukkan oleh tabel 3 .

\begin{tabular}{|c|c|c|c|c|}
\hline \multirow{2}{*}{ File } & \multicolumn{4}{|c|}{ Rata - Rata Hasil Ektraksi } \\
\hline & Contrast & Correlation & Energy & Homogeneity \\
\hline $\mathrm{S} 1$ & 0.3891 & 0.60816 & 0.2485 & 0.84424 \\
\hline $\mathrm{S} 2$ & 0.195 & 0.78397 & 0.3933 & 0.90908 \\
\hline S3 & 0.1411 & 0.75829 & 0.3894 & 0.9307 \\
\hline S4 & 0.2583 & 0.78812 & 0.3073 & 0.90124 \\
\hline S5 & 0.5304 & 0.71561 & 0.1871 & 0.83268 \\
\hline S6 & 0.3731 & 0.66107 & 0.3305 & 0.8803 \\
\hline S7 & 0.1506 & 0.87569 & 0.3888 & 0.93617 \\
\hline $\mathrm{S} 8$ & 0.1677 & 0.76038 & 0.4938 & 0.92676 \\
\hline S9 & 0.1701 & 0.79581 & 0.3484 & 0.92971 \\
\hline S10 & 0.2009 & 0.8949 & 0.2628 & 0.91103 \\
\hline S11 & 0.1703 & 0.89786 & 0.2573 & 0.91856 \\
\hline S12 & 0.2685 & 0.83695 & 0.3379 & 0.92073 \\
\hline S13 & 0.2167 & 0.91735 & 0.1844 & 0.91504 \\
\hline S14 & 0.1152 & 0.91221 & 0.3407 & 0.94253 \\
\hline S15 & 0.127 & 0.91736 & 0.2752 & 0.93948 \\
\hline B1 & 0.185 & 0.737 & 0.4171 & 0.95634 \\
\hline B2 & 0.1965 & 0.83179 & 0.3676 & 0.92999 \\
\hline B3 & 0.052 & 0.89059 & 0.6872 & 0.98028 \\
\hline B4 & 0.1257 & 0.91056 & 0.269 & 0.94661 \\
\hline B5 & 0.1516 & 0.89601 & 0.2654 & 0.93514 \\
\hline B6 & 0.1814 & 0.74762 & 0.5191 & 0.94716 \\
\hline B7 & 0.1611 & 0.85799 & 0.3423 & 0.93178 \\
\hline B8 & 0.1205 & 0.84067 & 0.4637 & 0.9465 \\
\hline B9 & 0.1289 & 0.80302 & 0.538 & 0.94445 \\
\hline B 10 & 0.1294 & 0.83245 & 0.3868 & 0.95433 \\
\hline B11 & 0.1355 & 0.8686 & 0.3254 & 0.93255 \\
\hline B12 & 0.119 & 0.9099 & 0.2933 & 0.94075 \\
\hline B13 & 0.116 & 0.88782 & 0.308 & 0.94227 \\
\hline B14 & 0.104 & 0.8405 & 0.3984 & 0.94825 \\
\hline B15 & 0.1056 & 0.89706 & 0.3574 & 0.95235 \\
\hline
\end{tabular}

\subsection{Proses Pengujian Klasifikasi (JST)}

Akurasi data diuji dengan menggunakan sebanyak 30 data. Proses pengujian klasifikasi (JST) sebagai berikut :

a. Membaca hasil ekstraksi citra data uji.

b. Menyesuaikan hasil ekstraksi ke data base yang telah dibuat pada pelatihan citra data uji.

c. Mengklasifikasikan citra uji yang di inputkan.

d. Hasil klasifikasi apakah citra uji tersebut termasuk ke dalam Daging Sapi (Halal) atau Daging Babi (Haram).

\subsection{Hasil Akurasi}

Setelah pengujian semua data yaitu, 15 citra daging sapi dan 15 citra daging babi, dapat dihitung tingkat akurasinya dengan menggunakan metode Recognition Rate.

$$
\text { Recognition Rate }=\frac{24}{30} \times 100 \%=80 \%
$$

Akurasi dari aplikasi Klasifikasi Citra Daging menggunakan metode (JST) dan ekstraksi ciri menggunakan (GLCM) yang telah dibangun sebesar $80 \%$.

\section{KESIMPULAN}

Kesimpulan yang dapat diambil dari pembuatan aplikasi klasifikasi citra daging menggunakan metode Jaringan Saraf Tiruan (JST) 
dengan ekstraksi ciri menggunakan Gray Level CoOccurence Matrix (GLCM) dapat disimpulkan.

Aplikasi klasifikasi daging ini dibuat menggunakan MATLAB dan dapat mengklasifikasi citra daging sapi atau babi yang di-inputkan dengan menggunakan metode Jaringan Saraf Tiruan (JST) dengan ekstraksi citra berdasarkan tekstur menggunakan Gray Level Co-Occurence Matrix (GLCM).

Tingkat akurasi aplikasi klasifikasi daging ini mencapai $80 \%$ dengan menggunakan 30 sample pengujian yang dibagi menjadi 15 daging sapi dan 15 daging babi. Parameter untuk daging sapi dengan Contras 0,115190 sampai 0,530430, Correlation 0,608160 sampai 0,917350, Energy 0,184360 sampai 0,493830, Homogeneity 0,832680 sampai 0,954330 . Parameter untuk daging babi dengan Contras 0,05205 sampai 0,26845, Correlation 0,737 sampai 0,91736, Energy 0,26899 sampai 0,6872, Homogenity 0,92073 sampai 0,98028

\section{DAFTAR PUSTAKA}

[1] A. Maulana, "Identifikasi Jenis Daging Menggunakan Image Processing Berbasis Android," Universitas Lampung, 2018.

[2] A. K. Jain, Fundamentals of Digital Image Processing. Davis: Prentice -Hall, inc., 1989.

[3] E. N, "Digital Image Processing : A Particial Introduction Using Java," The University of Michigan, Michigan, 2000.

[4] I. G. R. A. Sugiartha, M. Sudarma, and I. M. O. Widyantara, "Ekstraksi Fitur Warna, Tekstur dan Bentuk untuk Clustered-Based Retrieval of Images (CLUE)," Maj. Ilm. Teknol. Elektro, vol. 16, no. 1, p. 85, 2016, doi: 10.24843/mite.1601.12.

[5] L. J. Havery, Sistem Informasi. Jakarta: Mata Satu, 2000.

[6] S. Haykin, Neural Networks and Learning Machines, 3rd ed., vol. 3. Ontario: Library of Compress Catalog-In-Publication Data, 2008.

[7] A. A. Kasim and A. Harjoko, "Klasifikasi Citra Batik Menggunakan Jaringan Syaraf Tiruan Berdasarkan Gray Level CoOccurrence Matrices ( GLCM )," Semin. Nas. Apl. Teknol. Inf. Yogyakarta, 21 Juni 2014, pp. 7-13, 2014.

[8] W. Astuti, "Klasifikasi Citra Daging Sapi Dan Daging Babi Berdasarkan Ciri Warna Dan Tekstur," Universitas Islam Negeri Sunan Kalijaga Yogyakarta, 2016.

[9] M. M. Saleck, A. Elmoutaouakkil, and M. Moucouf, "Tumor detection in mammography images using fuzzy C-means and GLCM texture features," Proc. - 2017 14th Int. Conf. Comput. Graph. Imaging Vis. CGiV 2017, pp. 122-125, 2018, doi: 10.1109/CGiV.2017.22.

[10] R. Widodo, A. W. Widodo, and A. Supriyanto, "Pemanfaatan Ciri Gray Level Co-Occurrence Matrix ( GLCM ) Citra Buah Jeruk Keprok ( Citrus reticulata Blanco ) untuk Klasifikasi Mutu," J. Pengemb. Teknol. Inf. dan Ilmu Komput., vol. 2, no. 11, pp. 5769-5776, 2018.

[11] S. A. Wibowo, B. Hidayat, and U. Sunarya, "Simulasi dan Analisis Pengenalan Citra Daging Sapi dan Daging Babi dengan Metode GLCM dan KNN," Semin. Nas. Inov. Dan Apl. Teknol. Di Ind. 2016, pp. 338-343, 2016.

[12] R. Listia and A. Harjoko, "Klasifikasi Massa pada Citra Mammogram Berdasarkan Gray Level Cooccurence Matrix (GLCM)," IJCCS (Indonesian J. Comput. Cybern. Syst., vol. 8, no. 1, p. 59, 2014, doi: 10.22146/ijccs.3496.

[13] B. Library, "Citra Grayscale," Library.binus.ac.id, 2014. http://library.binus.ac.id/eColls/eThesisdoc/ Bab2/2014-2-00288-SK Bab2001 (accesed Oktober. 20, 2019).

[14] E. Isnianto, Hidayat N. Puspitaningrum, "Aplikasi Adaptive Neuro-Fuzzy Inference System (ANFIS) untuk Klasifikasi Suara Jantung sebagai Alat Bantu Diagnosis Gangguan Jantung," Seminar Nasional Teknologi Terapan - SNTT 2013, pp. 60-67, 2013.

[15] N. Ginanto, "Electric Transient Analysis Program (ETAP) Short Circuit Analysis," wordpress.com, 2012. https://novikaginanto.wordpress.com/2012/0 3/24/etap-electric-transient-analysisprogram/ (accesed Oktober. 20, 2019).

[16] R. R. P. Putri, M. T. Furqon, and B. Rahayudi, "Implementasi Metode JSTBackpropagation Untuk Klasifikasi Rumah Layak Huni," Jurnal Pengembangan Teknologi Informasi dan Ilmu Komputer, vol. 2, no. 10, pp. 3366-3372, 2018.

[17] N. D. Miranda, L. Novamizanti, and S. Rizal, "Convolutional Neural Network Pada Klasifikasi Sidik Jari Menggunakan Resnet50," Jurnal Teknik Informatika (Jutif), vol. 1, no. 2, pp. 61-68, 2020. 